\title{
Performance evaluation of groundwater management instruments: the case of irrigation sector in Tunisia
}

\author{
Aymen Frija ${ }^{a, *}$, Boubaker Dhehibi $^{a}$, Ali Chebil $^{b}$, Karen G Villholth $^{c}$ \\ ${ }^{\text {a }}$ Social, Economics and Policy Research Program (SEPRP), International Center for Agricultural \\ Research in the Dry Areas (ICARDA), P.O. Box 950764, Amman 11195, Jordan. (* Corresponding \\ author: Phone: (+962) (6) 5903120. Fax: (+962) (6) 5525930. E-mail address: a.frija@ @ cgiar.org; \\ frijaaymen@yahoo.fr) \\ ${ }^{\mathrm{b}}$ International Center for Agricultural Research in the Dry Areas (ICARDA), 3 Rue Mahmoud \\ Ghaznaoui, El Menzah IV, 1082 Tunis, Tunisia. \\ ${ }^{\mathrm{c}}$ International Water Management Institute (IWMI) South Africa; Private Bag X813, Silverton 0127, \\ Pretoria, South Africa
}




\begin{abstract}
Around $27 \%$ of aquifers in Tunisia are being overexploited. Groundwater extractions is mainly for the irrigation sector, where more than $40 \%$ of the water used for irrigation comes from GW sources. The objective of this study is to critically review and analyze GW management instruments adopted in Tunisia during the last four decades. Evaluation of current instruments was based on a set of criteria (the impact of the instrument on increasing water productivity, reducing aquifer withdrawals, acceptability of the instrument and its implementation cost) assessed through interviews with policy makers and experts, in addition to discussions at farmers' focus groups. Results show that regulatory instruments are widely used but weakly enforced, which can explain their limited impact. To be more effective, economic instruments need a better vertical interplay between different stakeholders. Analysis of stakeholders' participation shows limited awareness by farmers and a lack of collective actions for GW management at local levels. The alignment of GW policies to other cross-sectorial policies, the enhancement of the vertical interplay between water users' associations and local and national water administrations, and the horizontal integration of different water users and managers at the local and regional levels, are among the main recommendations of this study.
\end{abstract}

Keywords: Groundwater, irrigation, Governance, Regulation, Participation, WUAs, Tunisia 


\section{Introduction}

To date, the management of groundwater $(\mathrm{GW})$ around the world has been hampered by a variety of uncertainties linked to climate change and socioeconomic growth, as well as by ineffective governance structures affecting resource use, regulation and protection [1]. Effective GW governance is suggested by many authors as being among the most important challenges to ensure long-term sustainability of the sector Llamas and Martinez-Santos 2005 [2,3,4,5]; and most of the globally observed constraints to sustainable GW management can be attributed to the failure of its governance [6,7]. Governance refers both to setting objectives, principles and rules for managing the resource, and to processes for implementing the rules [8]. In line with this definition, GW governance can be described as the process by which GW is managed through the application of responsibility, participation, information availability, transparency, custom, and rule of law [9,10]. However, while knowledge of hydrology and hydro-geology linked to GW management has advanced, relatively little is known about the socioeconomic impacts of instruments and institutions governing GW use [32], as well as methodologies to assess their performances.

The problem of GW management is especially relevant for developing countries $[11,12,13]$ where institutions and management instruments are poorly designed and enforced. Even in developed countries, there are as yet few well-established examples of good practices and effective GW management [25]. In the MENA (Middle East and North Africa) region, GW withdrawal rates have been rising quickly $[11,14]$. This quick increase has been driven by the general policy trend of extending irrigated areas and decreasing the vulnerability of agricultural sectors to variable climate conditions. GWIn one of the latest briefs of the World Bank [40], it is clearly stated that not only physical water scarcity matters in the region, but also the related institutional and organizational failures of the sector. The report adds that technical investments for water development (and sanitation) in the region have not always been accompanied by the necessary institutional and policy changes, and are often not generating optimum economic returns. This is particularly true for the non-oil countries of the region including Tunisia, Morocco, Jordan, and Yemen [11,14,15,16,17]. For these countries, even though different instruments for GW management have been developed and applied [11] in parallel with GW development, a systematic and comprehensive review of these instruments as well as their performances in achieving sustainable $\mathrm{GW}$ use, is missing in the specialized literature.

This is also the case in Tunisia [11] where around $43 \%$ of irrigation water is GW [18]. Overall water resources in the country are estimated to be around $4700 \mathrm{Mm}^{3}$ per year [19] including $650 \mathrm{Mm}^{3}$ of nonrenewable GW resources (13.8\% of the total water resources) especially located in southern Tunisia. In 2008, annual surface water is estimated to $2700 \mathrm{Mm}^{3}$ while annual GW resources are estimated to be around $2000 \mathrm{Mm}^{3}$ [20]. GW in Tunisia is also characterized by unequal allocation and variable quality in terms of salinity. Most shallow GW resources (55\%) are situated in the north of Tunisia, while most deep (aquifer) resources (58\%) are in the south [21]. Good quality GW is only found in $8 \%$ of the shallow aquifers and $20 \%$ of the deep aquifers. If it is assumed that water with a salt content up to $3 \mathrm{~g} / \mathrm{L}$ can be used in the agricultural sector and for the production of drinking water, then approximately $36 \%$ of all GW resources are unsuitable [21]. Drought is another phenomenon with a significant effect on quality. In 
periods of drought, the salinity of water in shallow aquifers can reach $3.5 \mathrm{~g} / \mathrm{L}$, in some cases due to overextraction, as resources are drawn down for both domestic and irrigation purposes.

Shallow aquifers in Tunisia have been under increasing pressure, especially during the last three decades. Irrigated areas from wells and boreholes are slightly increasing and many aquifers are failing "everyday" [18,22]. This pressure was particularly high in the coastal (Cap Bon, Sahel and Gabes) and central regions (mainly Kairouan and Sidi Bouzid) [19]. The number of wells with traditional water pumps in Tunisia went from 60,415 in 1980 to 128,400 in 2000 with an increase of 5.6\% annually. This trend was also observed for wells equipped with solar-driven water pumps, of which the number increased from 23,061 in 1980 to 86,965 in 2000, a total increase of $19 \%$ annually. As a result there are many signs of aquifer depletion all over the country: of about 273 aquifers, 71 are overexploited at an average rate of $146 \%$ (46\% higher than their natural recharging rate) [22]. In contrast, GW policies in Tunisia are considered to be insufficient [11]. According to Faysse et al [11], it is rather clear that policy and institutional setting in Tunisia have been developed but their performance and effectiveness remains questionable and under-investigated. This takes us again to the need for a critical assessment of GW management instruments as well as their comprehensive performances assessment.

The objective of this paper is to contribute to the existing literature on the evaluation of GW instruments, through the case study of Tunisia. We particularly aim to provide a generic framework that can be used for systematic review and comprehensive assessment of GW management instruments and provide insights on how to improve their outcomes and effectiveness. To be able to provide such framework, we developed a set of performance indicators against which the performance and effectiveness of $\mathrm{GW}$ instruments can be assessed. The application of this analytical approach for the case of Tunisia is grounded on different information and primary/secondary data sources, including interviews with policy makers and experts, focus groups with farmers in different regions of Tunisia, as well as on official public documents and ministry reports. It is worth noting that the assessment of the performances of different GW instruments in this study is made based on the information collected from these different sources, including explicit perceptions and opinions of farmers and other stakeholders.

\section{Theoretical framework}

\subsection{Levels of $G W$ governance for analyzing management instruments}

The critical assessment undertaken in this paper of GW management instruments in Tunisia is based on the "Framework for Analyzing and Assessing GW Governance", developed by Wijnen et al. [14] in the framework of the "Water Partnership Program", led by the World Bank. Particularly, we will consider the three levels of GW governance analysis as stated by Wijnen et al. [14]. First, the national level (also called "level for setting policies") is highly important since it is the level where GW policies and management instruments are determined within the overall water policies. It also refers to the processes by which a nation establishes its objectives for GW and integrates these instruments with water, land and environment, and align and harmonize them with other related policies. The second level is called "strategic level" and corresponds to the governance functions. At this level enters the setting up of 
institutions and instruments needed to align stakeholders' behavior and actual outcomes to the GW policy objectives. Laws, rights, regulatory instruments, incentives, and other instruments of support to local water management, should all be considered as components of this strategic level. The final level is called "local level governance", which corresponds to the organizations and institutions that control actual outcomes on the ground and which responds (in varying degrees) to the rules and incentives from the strategic governance level [14]. This level includes: (1) public agencies, which are expected to reflect the national policies and instruments at the local level; (2) local collective management institutions, including local organizations; and (3) individual well owners, whose behavior is supposed to reflect the final outcome of the GW governance.

GW management instruments at the "strategic level" of governance can be divided into two main types [4,23,24,25,26]: regulatory or command-and-control policy instruments (e.g. GW access and use codes and GW use rights); and economic policy instruments. Economic policy instruments make use of financial sanctions and incentives such as GW pricing, transferability of water rights or pollution permits, subsidies and taxes (e.g. reducing pumping energy subsidies and tuning crop guarantee prices). Different types of instruments can be ideally combined for effective GW management [27].

At the local level governance, voluntary/advisory instruments, determined through community participation are considered to be supplementary tools for GW management. They include formal and informal instruments that motivate voluntary actions or behavioral changes without use of direct financial instruments.

\subsection{Different management instruments for different development ${ }^{1}$ levels of $G W$ extraction}

GW policies in different regions around the world have progressed and changed in parallel with development and often inevitable subsequent overexploitation and degradation of GW use. A generic pattern linking the evolution of GW policies and instruments used with the state of development (extraction) of the resource was provided by the World Bank [28]. According to this pattern, the baseline condition of GW exploitation is a situation where GW is available and accessible with adequate quality and the quantity exceeds a small dispersed demand. The needed management at this level is simply a registration of abstraction wells and captured springs. A next step corresponds to a growth of aquifer pumping, with only few local conflicts arising. Simple management tools such as appropriate well spacing are needed at this level. When significant stress starts to appear, a regulatory framework is needed. This framework needs to be settled based on comprehensive resource assessment with critical appraisal of aquifer linkages. This regulatory framework also needs to be complemented by a set of water demand management instruments when the exploitation of GW passes to a stage of unstable usufruct development. At this advanced stage, the aquifer is overused and abstraction exceeds the sustainable level of resource renewal. Based on these management targets, the analysis of the historical trend of GW resource development in Tunisia (or any other country), as well as its management instruments over time,

\footnotetext{
${ }^{1}$ The term of GW development is used by the WB to indicate the level of GW use at national level.
} 
should provide useful information about coherence between utilization and impact and monitoring/regulation in the country.

\section{3. $\quad$ Criteria to evaluate the performance of $G W$ management instruments}

In the broad literature on "evaluation and monitoring", it is conceptually known that evaluation of programs, projects, or institutions is defined as objective examination of their effectiveness and impact in the light of their specific objectives. This definition suggests that the evaluation criteria should be defined against the expected objectives of the management instruments (Table 1). The available literature concerning specific criteria used to evaluate GW management instruments is very limited. Most approaches in the literature are based on specific theoretical frameworks for policy analysis and evaluation (where the most important criteria are efficiency, effectiveness and equity of the implemented policies). Lenouvel and Montginoul [29] used five criteria to evaluate water policies in South France: (1) abatement level of the aquifer; (2) impact of the instrument on aggregate income; (3) acceptability; (4) predictability; and (5) durability of the instruments. Faysse et al. [11] used three criteria to evaluate different types of GW instruments applied in selected North African countries. These were related to the impact of the instrument on: (1) increase of water resource availability; (2) reduction of aquifer withdrawals; and (3) increase of water productivity. In the current paper, considering the broad objectives of GW management instruments, four indicators were developed based on Faysse et al. [11] (see table 1). For each evaluation criteria, table 1 summarizes the respective objective against which the GW instrument will be evaluated, and for which the criterion has been chosen. Table 1 also provides a practical description of the assessment of each of these criteria. The considered criteria can be presented as follows:

The impact of instruments on water productivity: At the farm and local levels these are used as first indicators. Such indicators are expressive of the impact of the instrument on producer (and even social) welfare. The Instruments' performance regarding their impact on water productivity was mainly based on interviews with regional administrators and experts, in addition to farmer focus group discussions.

The acceptability of the instrument: This is a key issue for the success of GW management instruments. The applied instruments have to be accepted by farmers and must be enforceable and then sustainable. In our case, we approximate this acceptability criterion by the enforcement level of the instruments. We assume that instruments that face enforcement problems, and a phenomenon of breach of the law, can be considered as modestly acceptable and sustainable. This criterion is considered from farmers' perspectives.

"Implementation degree" / “implementation cost": A management instrument must be effectively implemented to give positive expected impacts in the field. We consider two aspects as inherent to the implementation of an instrument. First, the feasibility which means the aptitude of a given instrument to be implemented in the current institutional, cultural, social and economic context. This is assessed based on opinions of experts and policy makers. The second aspect is implementation costs. An instrument can be implementable, but its implementation cost could be very high. Thus, implementation cost is also a 
very important determinant of the choice of instruments. In our case, both aspects described above were considered in the 'implementation criterion'.

Impact on the aquifer withdrawals: The used instrument has to be effective in terms of aquifer restoration/sustainability. This is why the last criterion for evaluation of GW management instruments has to be related to the impact of these instruments on aquifer withdrawals.

TABLE 1 about here

\section{Methodology}

The information used in this paper was collected in the framework of a broader project, by the African Development Bank (AfDB), on Agricultural Use of GW and Management Initiatives in the Maghreb (the region of Northwest Africa, west Egypt, i.e. Mauritania, Morocco, Algeria, Tunisia, and Lybia) (2011). The main findings from this research are published in Faysse et al., [11] as an AfDB policy brief. The information used for the current research derives from several levels. First, national public policies are reviewed, including those already officially defined, currently being implemented or even under ongoing discussions. Information about these policies are drawn from official public documents and ministry reports, and complemented by face-to-face interviews with key officials from central and regional agricultural administrations. These interviews were conducted during April-May 2011, and mainly aimed to assess opinions and perceptions of central and regional water administrators about achievements of GW instruments in Tunisia. A special focus was dedicated to the role of WUA in GW management, in addition to the main constraints of effective implementation and enforcement of these instruments at regional and local levels.

Second, at the local level, a number of case studies were conducted, including Nadhour/Zaghouan (Central Tunisia), and Nabeul (North-east), in order to focus on farmers' perceptions regarding ground water shortage and related management policies. The other objective of the field study was to assess the level of implementation, enforcement and control implied by the different GW management instruments, currently in use, from farmers' perspective. Face-to-face interviews with 15 farmers from Nadhour/Zaghouan were conducted in May 2011 and complemented by seven focus groups meetings in Nabeul and Nadhour/Zaghouan. Each focus group was exclusively conducted with 3 to 7 farmers during January-February 2013. The groups were asked to describe current mechanisms of GW management at the level of their irrigated areas, and which effects these instruments had on their agricultural activities. Assessment of farmers' expectations and constraints in regards to these instruments was also done via appropriate questions asked and mediated by a facilitator. For each single question, the group had to agree on one single response. Data collected from different focus groups, private farmers, and regional and central administrators has been analyzed through descriptive reporting of these stakeholders' opinions and perceptions. 
Both areas considered in this study are facing severe GW depletion. While the region of Nadhour/Zaghouan is facing a quantity shortage (GW aquifers are completely depleted in some cases), Nabeul region is however facing a quality shortage, where the overexploitation of GW resources is leading to seawater intrusion all through the coastal irrigated areas.

The average rainfall in the Nadhour/Zaghouan area is around $370 \mathrm{~mm} / \mathrm{year}$ with high inter-annual variability. The evapo-transpiration is also very high since the summer season is long (June-September) and dry. Summer temperatures can be as high as $46^{\circ} \mathrm{C}$ in July and/or August. GW is the main source for irrigation in the region. During the last decade, constant GW depletion (reaching sometimes 1 meter per year) and GW quality deterioration have been observed. The agricultural systems in this area are based on high water consuming vegetable crops including tomatoes, cucumbers, peppers, potatoes, watermelons and green pepper.

The region of Nabeul is also belonging to the semi-arid climate with average annual rainfall of 517 $\mathrm{mm} /$ year. Nabeul is located in an important strategic geographical position forming a peninsula covering $300 \mathrm{~km}$ of coastline. Both surface and GW is used for irrigation in this region. However, the overexploitation of $\mathrm{GW}$ in the costal irrigated areas is leading to important $\mathrm{GW}$ quality deterioration. Dominant crops in the region are fruit trees, followed by cereals, and vegetable crops.

\section{Results}

The presentation of our results is following the theoretical framework used in this research. The performance of GW instruments will be discussed at the three governance levels determined in the "Framework for Analyzing and Assessing GW Governance". The state of alignment of GW policies with other economic and development policies at the national level will firstly be discussed, and followed by a performance analysis of strategic regulatory and economic instruments. At a final stage, local-level instruments, related to the organizations and institutions in charge of the implementation of GW instruments, will also be assessed and discussed.

\subsection{Policies for $G W$ and alignment with other sectorial policies}

In Tunisia, even though agricultural usage of GW remains the highest, with more than $75 \%$ of the total GW use, several other sectors are using GW resources including tourism, mining, and urban. All of these sectors are important drivers for GW development and deterioration. However, the alignment of GW policies among the mentioned sectors has yet to be achieved [11]. In the 2014 revised "water law", more authority is given to the national and regional water management agencies in order to coordinate the use and management of GW among these sectors. But this new water law is still lacking clear statements for effective harmonization of GW irrigation policies with other economic and development policies, which may affect the sustainability of the GW resources. As stated in our theoretical framework in relation to the national level for setting GW policies, this concept of harmonization should go beyond the simple horizontal coordination between water sectors and other economic usages and verify that other economic policies are not conflictual to the stated GW ones. Such alignment would provide an effective framework for GW governance at the strategic level. 
Tunisia has been establishing a monitoring network of wells since the early 80 s, which can be considered as an important tool to control and monitor the GW conditions. The network comprises 2329 shallow wells and 1434 piezometers, with $36 \%$ of the network equipped with automatic data recording [30]. Groundwater quality, particularly in the coastal aquifers, is also assessed twice a year through $800 \mathrm{GW}$ quality control points equally distributed between shallow wells and boreholes. However, better accountability and quantification of the resource use and further enhancement of this network is still required [31]. It is noteworthy that most Tunisian aquifers subject to depletion are small to medium in size with a limited number of users, which may facilitate their monitoring, control and management.

\section{2. $\quad$ Strategic governance level: $G W$ instruments performances}

\subsubsection{Historical perspective}

Despite the low horizontal integration of Tunisian GW policies with other cross-sectorial policies, Tunisia showed a comprehensive integrated approach on viewing GW governance. A wide range of regulatory and economic instruments have been implemented [11] backed by the Tunisian 'water law' (Table 2). Before going into a detailed discussion of the performances of these instruments, this section briefly presents a historical account of GW use and accompanying policies. GW use and the instruments (including regulations, laws, incentives, taxes and subsidies) used in each main period of time are presented chronologically in Table 2.

\section{TABLE 2 about here}

Table 1 shows that water development in Tunisia has passed through different phases. During 19611975, only incipient stress was observed. At that stage, the objective of policy makers was to increase the irrigated areas through deployment of surface water and encouragement of GW exploitation. Water withdrawal in this stage was around $179 \mathrm{~m}^{3}$ per capita and per year. During 1976-1985, GW use peaked and significant stress started to be assessed in many irrigated areas. At this stage, the Government developed its first water law and a number of aquifers became protected. Prior authorization became mandatory for any new drilling. During 1986-1995, the same intensified trend in GW use was observed the stress was still significant, but further management instruments were considered. In fact, the government started to enhance water supply in overexploited areas (creation of 30 artificial recharge sites), and to consider GW and surface water together in management strategies instead of considering them separately. Decentralization of the agricultural and water administrations was also established at this stage.

From 1996 until now, the stress on GW has remained high and many signs of unstable development continue to appear. Aquifer depletion became common in many regions, while seawater intrusion was observed in almost all coastal areas. In 2001, a first update of the water law was instituted and another reform is currently underway. Main decisions and instruments adopted were: (i) establishment of the national program for water saving (offering farmers subsidies for water saving technologies); (ii) 
conducting studies about the possibility of introducing electricity-based tariffs in GW irrigated areas; and (iii) reform of WUA status in 2004, with the settlement of the following new objective: 'collective management and protection of natural resources (especially water) in their territories'.

\subsubsection{Widely-used but weakly-enforced regulatory instruments}

It is clear that GW management instruments were continuously updated with changes in GW depletion in Tunisia. However, at the strategic governance level, instruments and institutions need to be effectively operating in order to result in changing actual outcomes at the local level. It is so relevant to further analyze the effectiveness of these developed instruments against the objectives for which they have been designed. The set of performance indicators of GW management instruments, quoted in section 2.3, is used for this purpose.

In terms of regulatory instruments, the following regulations and legal instruments were introduced over time in Tunisia during the last three decades (see Table 3): (1) Requirement for an authorization for the pumping of GW resources deeper than 50 meters; (2) The classification of some overused aquifers as 'exclusion areas'. Within these areas, the exploitation of GW has to be strictly authorized by government administrations and these areas are specified and regulated through specific decrees; and (3) the classification of other more critical aquifers as 'prohibited areas'. Again, these are defined through specific decrees and concern areas where water resources are (or could be) insufficient with respect to actual and/or future planned needs. In these areas, all types of new wells become strictly prohibited and any infraction may be punished by law.

Regarding the third point above (prohibited areas), interviewed farmers state that when the location of illegal boreholes within these areas are known, intervention from the administration to enforce the law was rare [11]. After the 2010-2011 revolution, this phenomenon was deeply aggravated. Table 3 shows that this assessment regarding breach of the law is the same for all regulatory instruments. According to Mukherji and Shah [32], good conditions for law enforcement are likely to occur in countries where direct dependency on GW is low, farmers' economic conditions are better and the political situation is stable. However, in Tunisia, both the previous as well as the new political context have not encouraged enforcement of these laws. Before the revolution, corruption allowed illegal exploitation; while after the revolution the administration capacity for law enforcement became weak.

Other regulatory measures can be used locally, but do not belong to an overall implemented strategy. As an example, some regional/local administrations encouraged farmers to cultivate low water-consuming crops and this is sometimes imposed in areas where the water table condition is very critical. A full conversion of agricultural systems in such irrigated areas will, however, be difficult and will need a carefully studied strategy, in addition to governmental support and framing. When asked for their opinion, some farmers said that they were ready to shift their agricultural systems but did not have any 
knowledge of what could be a commercially and technically possible and suitable alternative (it is noteworthy mentioning that most farmers in Tunisia have a very low education level).

TABLE 3 about here

The introduction of many regulatory instruments in Tunisia can be explained by their low implementation cost compared to other instruments. However, based on our analysis, most regulatory instruments were also found to be not acceptable by farmers. In fact, breach of laws is widely observed among farmers and sanctions rarely applied. Then the question will be whether the government is ready to further invest in enhancing the enforcement of these regulations. Some experiences in Tunisia show that the marginal returns of such investments are highly attractive [41].

\subsubsection{Limited impact of the economic instruments}

The main economic (incentive) instruments used in Tunisia to deal with the overexploitation of GW are related to the National Program for Water Savings. This program offers farmers subsidies of 40-60\% of their investment costs in irrigation-saving technologies [11]. The program was established in 1995 and continues to be the main incentive aiming to reduce water use and enhance water productivity in irrigated areas in Tunisia. Table 3 shows that this instrument sis widely implemented in Tunisia despite its high implementation cost. The instrument also had a very positive impact on the assessed indicators. However, observations of water use and extension of irrigated areas at the national level during the last decade shows that overall water consumption in the agricultural sector was not reduced during this period [33,34] meaning that pressure on water resources has not been released. According to Al Atiri [35], irrigators have not yet fully mastered the modern technology. Moreover, the water saved has been mainly used to intensify the existing irrigated systems.

Another economic instrument used in Tunisia is water pricing - with the government using a WUAbased pricing approach. In fact, many publicly-managed small-scheme irrigated areas were created. In each of these irrigated areas, a WUA of few farmers is created to manage one single borehole and take the task of water allocation among its adherents. They are known in Tunisia as 'Petite et Moyenne Hydraulique' which means 'small and medium public irrigated areas' and cover $24 \%$ of the total public irrigated areas (including irrigated areas from sources other than GW). Farmers in these areas were obliged to join the WUA to benefit from the irrigation water, and avoid high investments in private boreholes. By using this method, farmers are obliged to pay for water, and water pumping can be easily controlled by the association. However, water fees applied by the WUA are in most cases only covering the variable operation and maintenance costs of the associations; which remains low and does not provide much incentives for changing users' behavior (Table 3).

Currently, there is also a debate on establishing an electricity-based pricing system for private boreholes. This idea is currently being negotiated between the Ministry of Agricultural and Hydraulic Resources (MAHR), and the Tunisian Company of Electricity and Gas. Controlling GW use through electricity 
metering and quotas has been used (or proposed) in many other countries [36,37]. Our assessment (Table 3) also shows an expected positive impact of this instrument. However, to our knowledge, no specific study on its actual application in Tunisia is currently available.

\subsection{Groundwater instruments at the local level}

\subsubsection{Enhancing vertical institutional interplay and creating horizontal coordination}

Many central administrations within the MAHR are involved in the GW exploitation, control and management in Tunisia. After the period of centralized agricultural water management through the Office for the Development of Medjerda Valley (Office de Mise en Valeur de la Vallée de la Medjerda, OMVVM), the Regional Agricultural Development Commissariats (CRDA) were created (in the late 1980s) in order to represent the (central) Ministry of Agriculture at regional levels. The dissolution of the OMVVM and the reinforcement of the role of the CRDAs in the regional irrigation planning, development, and monitoring can be considered as a major milestone in the reform for the Tunisian GW sector. In fact, parallel to this decentralization, local WUAs, including GW users' association, have been created with the main task of GW exploitation, monitoring and operation.

According to their statutes (Decrees No. 87-1261 and 87-1262, 27 October 1987), among the main objectives of WUAs are the exploitation of public water resources at local levels (public water resources can be either surface or $\mathrm{GW}$ ) to organize farmers in sub-districts, to ensure the delivery of irrigation water at farms level, to collect water fees from irrigators and to undertake any investments in order to accomplish these tasks. With more pressure on water resources, these objectives were adjusted by Law No. 2004-24, 15 March 2004, calling for increased participation and involvement of WUAs in water resource planning, investment and management.

WUAs can be considered as the backbone of the Tunisian GW strategy. Most of the economic and regulatory instruments, used to regulate GW use, are applied through/by the WUAs. This means that the impact of these policies will highly depend on the WUAs' performance. For example, GW pricing in Tunisia, which is basically done through WUA, does not imply reduction of over-pumping of GW by illegal farmers. Indeed, based on our interviews and discussions in focus groups, in many cases the weak maintenance of the irrigation network by the WUA and the low water reliability, lead some farmers to exit from WUA and dig their own (sometimes illegal) wells, which greatly restricts the impact of the GW pricing on reducing water withdrawals.

On the other hand, the low service quality and water reliability in some irrigated schemes are usually due to the absence of private maintenance companies. In these cases, the maintenance of the irrigation networks is exclusively done by the CRDA. A management contract, usually signed between the CRDA and the WUA, defines the rights and duties of each party. From our interviews with WUA managers, some of them declare that most of the supply reliability problems are due to slow interventions by the 
regional administration for maintenance and reparation. Many authors in Tunisia $[19,34]$ have called for a (juridical) clarification of the management contract, as the responsibilities and duties of WUAs and CRDAs are not yet well defined. On the other hand, the CRDAs have a specific unit responsible for the training monitoring and control of WUAs. In many of the CRDA visited during this study, the units employ 1-2 persons who sometimes manage more than 45 WUAs. They also suffer from lack of other various financial and technical resources. According to Shah [4], asking agencies and organizations more than their capacities can be a cause of GW management failure. Theesfeld [26] stated that when different authorities need to work together, ambiguity often exists in the definition of their respective central and local responsibilities. However, while the vertical interplay between GW management institutions in Tunisia exists but needs to be enhanced, the horizontal coordination for GW management is highly questioned [11]. There is definitely a need for a system of higher-level participation of users and stakeholders [23], which could be called 'aquifer management organizations' implying different users and managers of the GW resource. The government support to the small WUA is also questionable. Social arguments would probably not be enough in the near future to justify government support to WUA in very small irrigation schemes (of less than 50 ha in some cases).

\subsubsection{A major weakness: absence of effective executive agency for regulation enforcement}

Institutional and organizational trends in Tunisia shows that although many administrative reforms were undertaken, there is no efficient and effective executive agency for regulation enforcement, even though a 'water police' (mainly ensuring the enforcement of water regulations) exists is and required by the Tunisian water code [38]. Local interviewed actors were stating that exception of very rare cases, illegal practices are not severely punished by the administration [30] and also receive no other kind of social exclusion. Faced with this problem, the solution is either to further invest in promoting self-regulation, or to invest in enhancing regional and local administration capacities [4,23]. The best is of course a situation where both options are combined.

\subsubsection{Stakeholder participation: limited farmer awareness}

Many interviewed regional and local irrigation managers recognize that the application of the participatory approach in local irrigation problems is insufficiently solid. It is not yet completely integrated in the irrigation management habits of farmers and local managers, with only very low public investments devoted for it. The intervention of public administration for technical assistance and framing of this approach is also still very limited. WUA managers and regional administrations for GW management attribute the crisis of overexploitation and the lack of institutional arrangements to the fact that farmers only consider short-term benefits and are unwilling to consider future benefits within a sustainable framework of aquifer management. This was also understood from many farmers' responses and opinions. Accordingly, the relevant question will be about appropriate adjustments of the current policy, regulatory, and administrative frameworks to better frame farmers' behavior and change their perception of the resource. In this context, and in addition to all of the potential reforms and enhancements discussed above, Van der Voorn [42] demonstrate the added value of visions and vision 
development processes for improving resources management. Developing a vision should be prior to policy formulation that accommodate the different goals and worldviews of stakeholders for which visioning can account [42]. According to the same reference, the emerging shared vision has the potential to converge stakeholders on a commonly agreed upon problem articulation, goals and plausible directions for holistic goal fulfilment. The current ongoing reform of the water laws in Tunisia is declared to be based, among others, on stakeholders and social partners' consultation, with the hope that a shared vision will be developed to ensure more participation of different actors, particularly in the management of the GW resources.

\section{Concluding remarks}

This study provides a comprehensive framework for the analysis of performance of GW management instruments in Tunisia where GW is critically overexploited. The analysis was based on four criteria assessed through interviews with policy makers and experts, in addition to discussions in farmers' focus groups. The findings from the study showed a coherent trend in GW management policies and GW development in Tunisia during the last four decades. In fact, depending on the development levels of GW exploitation, Tunisia has developed a wide range of instruments intended to limit GW overexploitation. However, the current critical situation of the resource leads to further questions about the performance and effectiveness of the developed instruments. This aspect was also considered in our analysis and major results were documented. It seems that regulatory instruments are the most preferred by policy makers due to their low implementation costs, when not accompanied with effective implementation investments (Table 3). However, most of these instruments in Tunisia do not achieve their expected outcomes, mainly due to their very low enforcement. Moreover, economic instruments also exist in Tunisia, but their effect on reducing GW pumping is also considered to be limited in many cases mainly due to the need for enhanced vertical interplay between WUAs and the regional administration in operation and maintenance tasks. In cases of subsidies for irrigation-saving techniques, the saved water is generally used to extend the irrigated areas, which leads to the same overexploitation result. According to Lopez-Gunn et al. [39], solving water and food problems is not only a technical challenge but also a problem of fundamental ethical values and political will. This highlights the need for the Tunisian government policies to improve the administrative and organizational performances, and enhancing the enforcement level of the existing regulation through social advertising, ethical values changes and investments in stakeholders' participation. Furthermore, results also raise some fundamental questions especially in relation to the centralized regulation aspect in combination with local devolution of groundwater management. This approach seems to be incompatible with future sustainability of the resource. In terms of perspectives, much research scope exist in investigating the national level of policy setting, and analyzing the harmony between GW and other related economic and social policies. Furthermore, a comparative application of the "Framework for Analyzing and Assessing Groundwater Governance" for Tunisia and other countries applying similar trajectories and approaches, such as Spain, would probably provide valuable lessons, especially for the enhancement of the strategic governance level. 


\section{Acknowledgments}

This paper was partly undertaken as part of, and funded by, the CGIAR Research Program on Policies, Institutions, and Markets (PIM) led by the International Food Policy Research Institute (IFPRI). PIM is in turn supported by these donors.* The paper also partly benefited from the support of the Economic Research Service (ERS) - United States Department of Agriculture (USDA), as grant for the 'Agricultural Productivity with an Emphasis on Water Constraints in the Middle East and North Africa' of ICARDA. The opinions expressed here belong to the authors, and do not necessarily reflect those of PIM, IFPRI, or CGIAR".

\section{References}

[1] Knüppe, K, The challenges facing sustainable and adaptive groundwater management in South Africa. Water SA 37 (1) (2010) 67-73.

[2] Kretsinger, V., Narasimhan, T.N, California's evolution toward integrated regional water management: a long-term view. Hydrogeol. J. 14 (3) (2006) 407-423.

[3] Llamas and Martınez-Santos, P. M, The silent revolution of intensive groundwater use: Pros and Lons. Guest Editorial. Ground Water 43(2), (2005) 161.

[4] Shah, T, Groundwater and human development: challenges and opportunities in livelihoods and environment. Water Policy 51 (8) (2005) 27-37.

[5] Wang, J., Huang, J., Huang, Q., Rozelle, S, Privatization of Tube wells in North China: determinants and impacts on irrigated area, productivity and the water table. Hydrogeol. J. 14 (3) (2006) 275285 .

[6] Bakker, K. Koo, M, Governance failure: rethinking the institutional dimensions of urban water supply to poor households. World Dev. 36 (10) (2008) 1891-1915.

[7] Rogers, P., Hall, A.W, Effective water governance. TEC Background Papers No. 7. Global Water Partnership, Stockholm (2007).

[8] Ross, A., Martinez-Santos, P, The challenge of groundwater governance: case studies from Spain and Australia. Reg. Environ. Change 10, (2010) 299-310.

[9] Moench M., Kulkarni H., Burke J, Trends in local groundwater management institutions. Global Environmental Facility (GEF), Thematic paper $n^{\circ} 7$ (2013).

[10] Robert G. Varady R.G, Van Weert F, Megdal S.B, Gerlak A, Abdalla Iskandar C, and HousePeters L, Groundwater Policy and Governance. Global Environmental Facility (GEF), Thematic paper $n^{\circ} 5$ (2013).

[11] Faysse, N., Hartani, T., Frija, A., Marlet, S., Tazekrit, I, Agricultural use of groundwater and management initiatives in the Maghreb: Challenges and opportunities for sustainable aquifer exploitation. Economic Brief. African Development Bank, Tunis (2011).

[12] Siebert, S., Burke, J., Faures, J.M., Frenken, K., Hoogeven, J., Döll, P., Portmann, F.T, Groundwater use for irrigation - a global inventory. Hydrol. Earth Syst. Sc. 14, (2010) 1863-1880. 
[13] Braune, E., Xu, Y, The role of groundwater in Sub-Saharan Africa. Ground Water 48 (2) (2009) 229-238.

[14] Wijnen, M., Augeard, B., Hiller, B., Ward, C. and Huntjens, P, Managing the Invisible Understanding and Improving Groundwater Governance. Water Papers. (2012) World Bank

[15] Basu, N.B., Van Meter, K., Comprehensive Water Quality and Purification, Comprehensive Water Quality and Purification. Elsevier Editing. doi:10.1016/B978-0-12-382182-9.00062-1 (2014)

[16] Kharraz, J. El, El-Sadek, A., Ghaffour, N., Mino, E., Water scarcity and drought in WANA countries. Procedia Eng. 33, (2012) 14-29. doi:10.1016/j.proeng.2012.01.1172

[17] Molle, F., Venot, J.-P., Hassan, Y., Irrigation in the Jordan Valley: Are water pricing policies overly optimistic? Agric. Water Manag. 95, (2008) 427-438. doi:10.1016/j.agwat.2007.11.005

[18] MARH (Ministère de l'Agriculture et des Ressources Hydrauliques) Stratégie nationale d'adaptation de l'agriculture tunisienne et des écosystèmes aux changements climatiques, Tunis (2007).

[19] Al Atiri, R, Evolution institutionnelle et réglementaire de la gestion de l'eau en Tunisie, Vers une participation accrue des usagers de l'eau ; in Sami Bouarfa, Marcel Kuper, Abdelhafid Debbarh (ed) (2007). L'avenir de l'agriculture irriguée en Méditerranée. Nouveaux arrangements institutionnels pour une gestion de la demande en ea. Actes du séminaire Wademed, Cahors, France, 6-7 novembre 2006. CIRAD, Montpellier, France.

[20] INS (Institut Nationale des Statistiques), Annuaire des statistiques 1998-2010, (2010) Tunis.

[21] Benabdallah, S, The water resources and water management regimes in Tunisia. In: Agricultural Water Management: Proceedings of a Workshop in Tunisia (Series: Strengthening Science-Based Decision Making in Developing Countries), Holliday, L. (Ed). (2007) The National Academies Press, Washington, D.C.

[22] TICET (Tunis International Center for Environmental Technologies), Institutional framework and decision making practices for water management in Tunisia. Project Report of the CITET, March (2009).

[23] Foster, S. Garduño, H. Tuinhof, A., Tovey, C, Groundwater governance, conceptual framework for assessment of provision and needs. The World Bank (Water Partnership Program), Strategic Overview Series, Number 1, (2010).

[24] Giordano, M, Global groundwater? Issues and solutions. Annu. Rev. Env. Resour. 34, (2009) 7172.

[25] Kemper, K.E, Instruments and institutions for groundwater management. In the agricultural groundwater revolution: Opportunities and threats to development, edited by M. Giodano and K.G. Villholth, pp. 153 - 172. (2007) Oxford University Press.

[26] Theesfeld, I, Institutional challenges for national groundwater governance: policies and issues. Groundwater 48 (1), (2010) 131-142.

[27] Esteban, A., Dinar, A, Modeling sustainable groundwater management: Packaging and sequencing of policy interventions. J. Environ. Manage. 119, (2013) 93-102.

[28] World Bank, Groundwater Resource Management: an introduction to its scope and practice. Groundwater Management Advisory Team (GW.MATE). Briefing Note Series, Note 1. Washington, DC (2010). 
[29] Lenouvel, V., Montginoul M, Groundwater Management Instruments in a Conjunctive Use System: assessing the Impact on Farmers' Income Using a Mixed Integer Linear Programming (MILP). German Journal of Agricultural Economics, 59(3), (2010) p. 158-172.

[30] FAO, Groundwater management in Tunisia. Draft synthesis report, Rome (2009).

[31] Jousma, G., Roelofsen, F.J, worldwide inventory on groundwater monitoring. International Groundwater Resources Assessment Centre (IGRAC); Report nr. GP 2004-1, (2004)

[32] Mukherji, A., Shah, T, Groundwater socio-ecology and governance: a review of institutions and policies in selected countries. Hydrogeol. J. 13, (2005) 328-345.

[33] Bachta, M.S, Elloumi, M, Analyse des politiques hydrauliques en Tunisie: quelques éléments d'évaluation. In: Les défis de la terre : l'agriculture en Espagne et en Tunisie face aux défis de la libéralisation, ouvrage collectif. F., Elloumi M., Gallardo R., Sai M. B., (s/d). Cérès Editions et IRESA, Tunis (2005).

[34] Frija, A, Efficiency analysis of the irrigation water management institutions in Tunisia. PhD thesis, Ghent University (2009).

[35] Al Atiri, R, Les efforts de modernisation de l'agriculture irriguée en Tunisie. Paper presented at: Séminaire Modernisation de l'Agriculture Irriguée, Rabat, Morocco, 19-23 April (2004).

[36] Mukherji, A, The energy-irrigation nexus and its impact on groundwater markets in eastern IndoGangetic basin: Evidence from West Bengal, India. Energy Policy 35 (12), (2007) 6413-6430.

[37] Zekri, S, Controlling groundwater pumping online. J. Environ. Manage. 90 (11), (2009) 35813588 .

[38] ACSAD: Arab Center for the Studies of Arid Zones and Dry Lands, Management, protection and sustainable use of groundwater and soil resources in the Arab region. Project Report No. 1996.2189.7, Volume 5 (2003).

[39] Lopez-Gunn E., De Stefano L., Llamas M.R, The role of ethics in water and food security: balancing utilitarian and intangible values, Water Policy 14 (2012) 89-10

[40] World Bank, Making the Most of Scarcity: Accountability for Better Water Management Results in the Middle East and North Africa. Washington DC (2007).

[41] Frija, Iheb; Frija, Aymen; Leghrissi, Hafsia; Faysse, Nicolas; Marlet, Serge, 2014. Dynamique d'émergence d'une gestion collective d'eau souterraine dans un périmètre irrigué privé dans le Sud tunisien. Colloque international "Agricultures familiales, territoires et perspectives de développement dans les Suds", 11-13 décembre 2014, Tunis, IRMC.

[42] Van der Voorn, T., Pahl-Wostl, C., Quist, J. (2012) Combining backcasting and adaptive management for climate adaptation in coastal regions: A methodology and a South African case study. Journal of Futures 44, 346-364. 
TABLE 1 - Selected evaluation criteria for GW management instrument

\begin{tabular}{|c|c|c|}
\hline Objectives of GW instruments & $\begin{array}{c}\text { Selected evaluation } \\
\text { Criteria }\end{array}$ & Assessment of the Criteria \\
\hline $\begin{array}{l}\text { The instrument should not be } \\
\text { counterproductive (at the farm } \\
\text { level) }\end{array}$ & $\begin{array}{l}\text { "The impact of instruments } \\
\text { on water productivity" }\end{array}$ & $\begin{array}{l}\text { Farmers' perception bout the potential effect of the } \\
\text { instrument on their farming activities and overall } \\
\text { income, }\end{array}$ \\
\hline $\begin{array}{l}\text { The instrument has to be } \\
\text { accepted by farmers and thus } \\
\text { easily enforceable, }\end{array}$ & $\begin{array}{l}\text { "The acceptability of the } \\
\text { instrument" }\end{array}$ & $\begin{array}{l}\text { Opinion of regional stakeholders (including farmers) } \\
\text { about the level (and constraints) of enforcement of } \\
\text { the instrument in their respective regions, }\end{array}$ \\
\hline $\begin{array}{l}\text { The instrument should not be } \\
\text { costly and can be adapted to } \\
\text { different contexts over the } \\
\text { country }\end{array}$ & $\begin{array}{l}\text { "Implementation level" / } \\
\text { "implementation cost" }\end{array}$ & $\begin{array}{l}\text { Secondary data about the scope of implementation of } \\
\text { the instrument in the country; and experts }{ }^{(1)} \text { opinion } \\
\text { about its implementation cost, }\end{array}$ \\
\hline $\begin{array}{l}\text { The instrument should help } \\
\text { stabilizing the piezometric levels } \\
\text { of aquifers }\end{array}$ & $\begin{array}{l}\text { "Impact on the aquifer } \\
\text { withdrawals" }\end{array}$ & $\begin{array}{l}\text { Stakeholders' perceptions about the stability of } \\
\text { piezometric levels after the implementation of the } \\
\text { instrument, and conditions for such improvement to } \\
\text { happen (if it didn't happen yet), }\end{array}$ \\
\hline
\end{tabular}

(1) From the central administration of the Ministry of Agriculture. 
TABLE 2 - Characterization of the GW (GW) development period and corresponding management instruments in Tunisia.

\begin{tabular}{|c|c|c|c|c|c|c|}
\hline \multirow[b]{2}{*}{ Period } & \multicolumn{5}{|c|}{ Ratios/exploitation indicators } & \multirow[b]{2}{*}{ Management instruments (brief description) } \\
\hline & $\begin{array}{l}\text { Freshwater } \\
\text { withdrawals as } \\
\text { percentage of } \\
\text { total renewable } \\
\text { water resources }\end{array}$ & $\begin{array}{l}\text { Agricultural } \\
\text { water } \\
\text { withdrawals as } \\
\text { percentage of } \\
\text { total water } \\
\text { withdrawals }\end{array}$ & $\begin{array}{l}\text { Total water } \\
\text { withdrawals } \\
\text { per capita }\end{array}$ & $\begin{array}{l}\text { Area } \\
\text { equipped for } \\
\text { irrigation by } \\
\text { GW ( } 1000 \\
\text { ha) }\end{array}$ & $\begin{array}{l}\text { Share of } \\
\text { agricultural } \\
\text { GDP }\end{array}$ & \\
\hline $\begin{array}{l}\text { (1961-1975) } \\
\text { Incipient } \\
\text { stress }\end{array}$ & $23.3 \%$ & - & $\begin{array}{l}179 \\
\mathrm{~m}^{3} / \text { inhb/year } \\
(1975 \text { value })\end{array}$ & & $\begin{array}{l}21.7 \% \\
\text { (average } \\
1967-1972 \text { ) }\end{array}$ & $\begin{array}{l}\text { - Water supply enhancement: focus on surface water resource supply } \\
\text { enhancement }\end{array}$ \\
\hline $\begin{array}{l}\text { (1975-1985) } \\
\text { GW use peak } \\
\text { Significant } \\
\text { stress }\end{array}$ & $\begin{array}{l}45.7 \% \\
\text { Average (1980- } \\
1985)\end{array}$ & - & $\begin{array}{l}289.2 \\
\mathrm{~m}^{3} / \text { inhb/year } \\
\text { (average } \\
1980-1985)\end{array}$ & & $\begin{array}{l}17.7 \% \\
\text { (average } \\
1977-1992 \text { ) }\end{array}$ & $\begin{array}{l}\text { - Creation of the water law (1975) } \\
\text { - A number of aquifers become protected and drilling becomes subject to prior } \\
\text { approval }\end{array}$ \\
\hline $\begin{array}{l}(1985-1995) \\
\text { Significant } \\
\text { stress }\end{array}$ & $\begin{array}{l}64.2 \% \\
\text { Average (1990- } \\
1995)\end{array}$ & $\begin{array}{l}87.2 \% \\
\text { (Average } \\
1990-1995)\end{array}$ & $\begin{array}{l}336.2 \\
\mathrm{~m}^{3} / \text { inhb/year } \\
(\text { average } \\
1990-1995)\end{array}$ & $\begin{array}{l}216(1991 \\
\text { value })\end{array}$ & $\begin{array}{l}17.7 \% \\
\text { (average } \\
1977-1992)\end{array}$ & $\begin{array}{l}\text { - Enhancing water supply in overexploited aquifers areas: creation of } 30 \\
\text { artificial recharge sites } \\
\text { - Consider surface water and GW together in management strategies } \\
\text { - Decentralization of agricultural administrations and more autonomy to WUAs }\end{array}$ \\
\hline $\begin{array}{l}\text { (1995-2001) } \\
\text { Significant } \\
\text { stress/unstabl } \\
\text { e development }\end{array}$ & $\begin{array}{l}61.6 \% \\
\text { (2001 value) }\end{array}$ & $\begin{array}{l}75.9 \% \\
\text { (2001 value) }\end{array}$ & $\begin{array}{l}295.8 \\
\mathrm{~m}^{3} / \text { inhb/year } \\
(2001 \text { value })\end{array}$ & $\begin{array}{l}225(2000 \\
\text { value })\end{array}$ & $\begin{array}{l}12.6 \% \\
\text { (1997 value) }\end{array}$ & $\begin{array}{l}\text { - Adoption of the water management approach } \\
\text { - Establishment of the national program for water saving }\end{array}$ \\
\hline $\begin{array}{l}\text { (2001- } \\
\text { current) } \\
\text { Unstable } \\
\text { development }\end{array}$ & - & - & & $\begin{array}{l}271.8(2006 \\
\text { value) }\end{array}$ & $\begin{array}{l}9.01 \% \\
\text { (average } \\
2002-2011 \text { ) }\end{array}$ & $\begin{array}{l}\text { - In } 2001 \text { update of the water law of } 1975 \\
\text { - Current reforms of the water laws started in } 2012 \\
\text { - Studying the alternative of introducing electricity-based tariff in GW irrigated } \\
\text { areas } \\
\text { - Reform of WUA status in } 2004 \text { with settlement of the following new } \\
\text { objective: 'Collective management and protection of natural resources } \\
\text { (especially water)' }\end{array}$ \\
\hline
\end{tabular}

Source: Own elaboration (from FAO Aquastat) and based on the WB methodology (2002-2006). 
TABLE 3 - Performance valuation of different GW (GW) management instruments used in Tunisia.

\begin{tabular}{|c|c|c|c|c|c|c|}
\hline \multirow{2}{*}{$\begin{array}{c}\text { Type of } \\
\text { instrument }\end{array}$} & \multirow[t]{2}{*}{ Instruments } & \multicolumn{4}{|c|}{ Expected impacts } & \multirow{2}{*}{$\begin{array}{l}\text { Challenges facing the } \\
\text { effectiveness of the } \\
\text { instruments }\end{array}$} \\
\hline & & $\begin{array}{c}\text { Increased water } \\
\text { productivity } \\
\text { (Expected/assessed) }\end{array}$ & $\begin{array}{c}\text { Reduction in aquifer } \\
\text { withdrawals } \\
\text { (Expected/assessed) }\end{array}$ & $\begin{array}{c}\text { Acceptability } \\
\text { (Expected/assessed) }\end{array}$ & $\begin{array}{c}\text { Implementation } \\
\text { level/ } \\
\text { implementation cost }\end{array}$ & \\
\hline \multirow[t]{4}{*}{$\begin{array}{l}\text { Regulatory } \\
\text { instruments }\end{array}$} & $\begin{array}{l}\text { Requirement of an } \\
\text { authorization for } \\
\text { exploiting GW deeper } \\
\text { than } 50 \mathrm{~m}\end{array}$ & $\mathrm{No} / \mathrm{No}$ & $\mathrm{Yes} / \mathrm{No}^{(1)}$ & $-/ \mathrm{No}$ & Wide/very low & Enforcement of the instrument \\
\hline & Exclusion areas & $\mathrm{No} / \mathrm{No}$ & $\mathrm{Yes} / \mathrm{No}^{(1)}$ & $-/ \mathrm{No}$ & Wide/very low & Enforcement of the instrument \\
\hline & Prohibited areas & $\mathrm{No} / \mathrm{No}$ & $\mathrm{Yes} / \mathrm{No}^{(1)}$ & $-/ \mathrm{No}$ & Wide/very low & Enforcement of the instrument \\
\hline & $\begin{array}{l}\text { Support conversion to } \\
\text { lower water-consuming } \\
\text { crops }\end{array}$ & Yes/Yes & Yes/- & - & Rare/very low ${ }^{(2)}$ & $\begin{array}{l}\text { Not instituted by law and } \\
\text { farmers face no obligations }\end{array}$ \\
\hline \multirow{3}{*}{$\begin{array}{l}\text { Economic } \\
\text { (incentive) } \\
\text { instruments }\end{array}$} & $\begin{array}{l}\text { Support conversion to } \\
\text { water saving technologies }\end{array}$ & Yes/Yes & Yes/yes ${ }^{(3)}$ & Yes/Yes & Wide/very high & High cost of implementation \\
\hline & $\begin{array}{l}\text { Tariffs for GW through } \\
\text { WUA }\end{array}$ & $\mathrm{Yes} / \mathrm{No}^{(4)}$ & $\mathrm{Yes} / \mathrm{No}^{(5)}$ & $-/ Y e s$ & $\begin{array}{l}\text { Wide/relatively } \\
\text { high }\end{array}$ & $\begin{array}{l}\text { Setting the appropriate price of } \\
\text { GW which can reduce the } \\
\text { overuse of the resource }\end{array}$ \\
\hline & Increased electricity price & Yes/- & Yes/- & Yes/Yes ${ }^{(6)}$ & $\begin{array}{l}\text { Not yet } \\
\text { implemented/ } \\
\text { relatively low }\end{array}$ & Prohibitive implementation cost \\
\hline \multirow[t]{2}{*}{$\begin{array}{l}\text { Local level } \\
\text { governance }\end{array}$} & $\begin{array}{l}\text { Promoting establishment } \\
\text { of WUA in GW irrigated } \\
\text { areas }\end{array}$ & $\mathrm{Yes}_{\mathrm{T} / \mathrm{Yes}}^{(7)}$ & Yes/No & $\mathrm{Yes}_{\mathrm{Y}} \mathrm{Yes}^{(7)}$ & $\begin{array}{l}\text { Wide/ relatively } \\
\text { high }\end{array}$ & $\begin{array}{l}\text { Difficult to implement in private } \\
\text { irrigated areas }\end{array}$ \\
\hline & $\begin{array}{l}\text { Social advertising and } \\
\text { farmers education }\end{array}$ & $\mathrm{Yes}^{(8)} / \mathrm{Yes}$ & $\mathrm{Yes}^{(8)} / \mathrm{Yes}$ & Yes/Yes & Limited/high & $\begin{array}{l}\text { High cost of } \\
\text { implementation/lack of } \\
\text { administrative resources of } \\
\text { agencies responsible for these } \\
\text { tasks }\end{array}$ \\
\hline
\end{tabular}

Source: own elaboration; (1) mainly because they are not well enforced; (2) except if farmers are given subsidies to support cropping changes; (3) if the saved water will not be used to extend irrigated areas; (4) water tariffs are very low compared to total farming costs; (5) low supply reliability leads farmers to dig their own wells; (6) if such a electricity pricing will be stated by law, we assume farmers will have no option but to accept it (case of India); (7) provided that WUA performs well; (8) effect assessed in the long-term. 